\title{
Pengaruh Suhu Awal dan Lama Penyeduhan terhadap Karakteristik Sensoris dan Warna Teh Putih Silver Needle (Camellia assamica) \\ Produksi PT. Bali Cahaya Amerta
}

The Effect of The Initial Temperature and Brewing Time on The Sensory Characteristics and Color of White Tea Silver needle (Camellia assamica) Produced by PT. Bali Cahaya Amerta.

\author{
I Wayan Eggy Perdana Putra, Luh Putu Wrasiati*, Ni Made Wartini \\ PS Teknologi Industri Pertanian, Fakultas Teknologi Pertanian, Universitas Udayana, Kampus Bukit \\ Jimbaran, Badung, Kode pos : 80361; Telp/Fax : (0361) 701801
}

Diterima 21 Agustus 2020 / Disetujui 27 Agustus 2020

\begin{abstract}
White tea is obtained from the shoots of Camellia assamica tea which are very young and still curled, have very fine silvery-white hairs or silver, and are kept out of the sun during the plucking process. Silver needle white tea produced by PT. Bali Cahaya Amerta is an excellent product promoted as functional drink. This research aimed to know the influence of initial temperature, and brewing time on the sensory characteristics and the color of silver needle tea; to decide the best initial temperature and brewing time in producing silver needle white tea. The design of experiment in this research used completely randomized design of organoleptic test and randomized complet block factorial in color intensity test with two treatment factors. The first factor was the initial brewing temperature which consisted of three levels namely, $75^{\circ} \pm 1^{\circ} \mathrm{C}, 85^{\circ} \pm 1^{\circ} \mathrm{C}, 95^{\circ} \pm 1^{\circ} \mathrm{C}$. The second factor was the brewing time which consisted of three levels namely, three minutes, six minutes, and nine minutes. The analyzed variable was organoleptic characteristics, such as hedonic (the whole receiver), color score, taste, as well as aroma and color intensity system $L^{*}, a^{*}, b^{*}$. The result of the research showed that the initial temperature and brewing time as well as the interaction of the two has a very significant effect to the whole tested variables. The treatment using $95^{\circ} \mathrm{C}$ initial temperature and nine minutes of brewing time produced the best characteristic, in which the color $2.40 \pm 0.64$ (limpidly yellowish to yellowish), taste $4.24 \pm 0.43$ (slightly sweet to sweet), aroma $4.48 \pm 0.51$ (has a tea scent to extremely tea scent), the whole receiver $6.20 \pm 0.43$ (like to extremely like), brightness level $\left(L^{*}\right) 55.32 \pm 0.17$, redness level $\left(a^{*}\right)$ $16.32 \pm 0.17$, yellowish level $\left(b^{*}\right) 36.37 \pm 0.10$.
\end{abstract}

Keywords: white tea, initial temperature, brewing time, organoleptic, color intensity.

\section{ABSTRAK}

Teh putih diperoleh dari pucuk daun teh Camellia assamica yang masih sangat muda dan masih menggulung, memiliki rambut-rambut sangat halus berwarna putih keperakan atau silver, dan pada saat proses pemetikan dihindarkan dari sinar matahari. Teh putih silver needle yang di produksi oleh PT. Bali Cahaya Amerta merupakan produk unggulan yang dipromosikan sebagai minuman fungsional. Tujuan penelitian ini adalah mengetahui pengaruh suhu awal dan lama penyeduhan terhadap karakteristik sensoris dan warna teh putih silver needle dan menentukan suhu awal dan lama penyeduhan terbaik untuk menghasilkan teh putih silver needle. Percobaan dalam penelitian ini menggunakan

*Korespondensi Penulis:

Email: wrasiati@unud.ac.id 
Rancangan Acak Lengkap untuk uji organoleptik dan Rancangan Acak Kelompok Faktorial pada uji intensitas warna, dengan dua faktor sebagai perlakuan. Faktor pertama yaitu suhu awal penyeduhan yang terdiri dari 3 taraf yaitu $75^{\circ} \pm 1^{\circ} \mathrm{C}, 85^{\circ} \pm 1^{\circ} \mathrm{C}, 95^{\circ} \pm 1^{\circ} \mathrm{C}$. Faktor kedua yaitu lama penyeduhan yang terdiri dari tiga taraf yaitu 3 menit, 6 menit dan 9 menit. Variable yang dianalisis adalah sifat organoleptik yaitu hedonik (penerimaan keseluruhan), skor warna, rasa, dan aroma dan intensitas warna sistem L*, a*, b*. Hasil penelitian menunjukkan bahwa suhu awal dan lama penyeduhan serta interaksi antar keduanya berpengaruh sangat nyata terhadap seluruh variabel yang diuji. Pelakuan suhu awal $95^{\circ} \mathrm{C}$ dan lama penyeduhan 9 menit menghasilkan karakteristik terbaik dengan warna 2,40 $\pm 0,64$ (bening kekuningan sampai kekuningan), rasa 4,24 $\pm 0,43$ (agak manis sampai manis), aroma 4,48 $\pm 0,51$ (beraroma teh sampai sangat beraroma teh), penerimaan keseluruhan 6,20 $\pm 0,43$ (suka sampai sangat suka), tingkat kecerahan $\left(\mathrm{L}^{*}\right)$ 55,32 $\pm 0,17$, tingkat kemerahan $\left(\mathrm{a}^{*}\right)$ 16,32 $\pm 0,17$, tingkat kekuningan ( $\mathrm{b}^{*}$ ) $36,37 \pm 0,10$.

Kata kunci: teh putih, suhu awal penyeduhan, lama penyeduhan, organoleptik, intensitas warna.

\section{PENDAHULUAN}

Teh putih merupakan teh yang dikembangkan di Indonesia sebagai minuman fungsional seperti halnya teh hijau (Gramza, 2008). Teh putih berasal dari pucuk daun teh Camellia assamica yang masih sangat muda dan masih menggulung, memiliki rambut-rambut sangat halus berwarna putih keperakan atau silver, dan pada saat proses pemetikan dihindarkan dari sinar matahari (Dias et al., 2013). Teh putih silver needle yang di produksi oleh PT. Bali Cahaya Amerta merupakan produk unggulan yang dipromosikan sebagai minuman fungsional. PT. Bali Cahaya Amerta merupakan salah satu perusahaan di Bali yang bergerak di bidang pangan khususnya di bidang perkebunan dan pengolahan teh.

Umumnya teh dikonsumsi dalam bentuk minuman dengan cara menyeduh pada suhu dan waktu tertentu. Suhu penyeduhan dan waktu akan mempengaruhi karakteristik organoleptik, fisik dan kimia dari seduhan teh (Prabawati, 2015). Menurut Rohdiana (2008), faktor-faktor yang mempengaruhi proses penyeduhan teh adalah suhu air, kondisi penyeduhan, lama penyeduhan dan kualitas air. Air yang digunakan harus memenuhi standar kualitas air baik dari segi parameter mikrobiologi, kimia an-organik, fisik dan kimiawi. Semakin tinggi suhu air yang digunakan pada proses penyeduhan maka, kemampuan air dalam mengekstrak kandungan kimia yang terdapat dalam teh akan semakin tinggi.Lama penyeduhan mempengaruhi kadar bahan terlarut, intensitas warna, dan aroma. Bertambahnya waktu penyeduhan maka kesempatan kontak antara air penyeduh dengan teh semakin lama sehingga proses ekstraksi menjadi lebih sempurna dan kandungan polifenol total semakin meningkat sampai batas tertentu dengan jumlah zat terlarut atau senyawa yang diinginkan telah habis di dalam bahan.

Ramlah (2017) menyatakan bahwa suhu dan waktu optimum penyeduhan teh hijau adalah suhu $85^{\circ} \mathrm{C}$ dan waktu 5 menit dengan karakteristik kafein sebesar 1,239\% dan tanin sebesar 3,506\%. Penelitian Somantri (2012) menunjukkan bahwa suhu dan waktu penyeduhan teh putih suhu $95^{\circ} \mathrm{C}$ dan waktu penyeduhan 9 menit menghasilkan polifenol paling tinggi yaitu $6,01 \%$. dan $\mathrm{IC}_{50}$ DPPH paling efektif yaitu 34,41ppm. Menurut Haras et al. (2017) menyatakan bahwa hasil pengujian tingkat kesukaan teh daun binahong dengan rasa, aroma dan warna yang disukai panelis adalah sampel dengan metode suhu penyeduhan $100^{\circ} \mathrm{C}$ dan waktu penyeduhan 7 menit. Dewata et al. (2017) menyatakan bahwa hasil perlakuan terbaik pada teh daun alpukat adalah perlakuan dengan suhu $100^{\circ} \mathrm{C}$ dan waktu penyeduhan 5 menit dengan karakteristik sensoris warna hijau kecokelatan, aroma yang disukai agak 
tidak khas teh herbal daun alpukat, dari segi rasa agak pahit, serta penerimaan keseluruhan yang diterima dengan baik.

Atribut sensori merupakan kumpulan kata untuk mendeskripsikan karakteristik sensoris pada suatu produk pangan, diantaranya adalah warna, rasa, dan aroma (Hayati et al., 2012). Warna memberikan kesan apakah produk tersebut akan disukai atau tidak, rasa merupakan salah satu faktor yang menentukan kualitas produk, dan aroma umumnya dapat meningkatkan daya tarik produk tersebut (Antara dan Wartini, 2014). Pengujian sensori berperan penting dalam pengembangan produk dengan meminimalkan resiko dalam pengambilan keputusan. Panelis dapat mengidentifikasi sifat-sifat sensori yang akan membantu untuk mendeskripsikan produk.

Teh putih silver needle merupakan teh unggulan produksi PT. Bali Cahaya Amerta. Penerimaan konsumen terhadap suatu produk diawali dengan penilaiannya terhadap warna, rasa dan aroma. Saat ini belum diketahui suhu dan waktu yang tepat untuk melakukan proses penyeduhan untuk mendapatkan karakteristik sensoris dan warna teh putih yang baik. Oleh sebab itu, perlu dilakukan penelitian dengan tujuan untuk mengetahui pengaruh suhu awal dan lama penyeduhan terhadap karakteristik sensoris dan warna teh putih silver needle dan menentukan perlakuan terbaik untuk menghasilkan teh putih silver needle (Camellia assamica) produksi PT. Bali Cahaya Amerta.

\section{METODE PENELITIAN}

\section{Tempat dan Waktu}

Penelitian ini dilakukan di Laboratorium Rekayasa Proses dan Pengendalian Mutu, Laboratorium Analisis Pangan, Laboratorium Teknik Pasca Panen, Fakultas Teknologi Pertanian, Universitas Udayana. Waktu pelaksanaan penelitian pada Maret hingga Mei 2020.

\section{Bahan dan Alat}

Bahan yang digunakan dalam penelitian adalah teh putih silver needle produksi PT. Bali Cahaya Amerta, Aquades sebagai pelarut untuk ekstraksi.

Peralatan yang digunakan dalam penelitian ini antaralain color reader, teko listrik pemanas air (Arashi), botol sampel, magnetik stirre, termometer, kertas saring, timbangan analitik (Shimadzu), beaker glass (Pyrex), aluminium foil, kertas label, Cup $100 \mathrm{ml}$, kuisioner, dan sendok stainless steel.

\section{Rancangan Percobaan}

Percobaan dalam penelitian ini menggunakan Rancangan Acak Lengkap untuk uji organoleptik dengan sampel 9 unit dan 25 kali pengulangan (25 orang panelis). Uji intesitas warna menggunakan Rancangan Acak Kelompok Faktorial dengan dua faktor sebagai perlakuan. Faktor pertama yaitu suhu awal penyeduhan yang terdiri dari 3 taraf yaitu $75^{\circ} \pm 1^{\circ} \mathrm{C}, 85^{\circ} \pm 1^{\circ} \mathrm{C}, 95^{\circ} \pm 1^{\circ} \mathrm{C}$. Faktor kedua yaitu lama penyeduhan yang terdiri dari tiga taraf yaitu 3 menit, 6 menit dan 9 menit. Dari 2 faktor di atas diperoleh 9 kombinasi perlakuan yang dilakukan dan masing-masing perlakuan dikelompokkan sebanyak 2 kali sehingga diperoleh sebanyak 18 unit percobaan. Data dianalisis dengan sidik ragam menggunakan Minitab 17. Apabila terdapat pengaruh perlakuan terhadap parameter yang diamati, maka akan dilanjutkan dengan uji Tukey 5\%. Penentuan perlakuan terbaik dilakukan dengan uji indeks efektivitas (De Garmo et al., 1984).

\section{Pelaksanaan Penelitian \\ Pembuatan ekstrak teh putih (Ramlah, 2017).}

Pembuatan ekstrak teh putih menggunakan metode penyeduhan menurut Ramlah (2017) dengan modifikasi. Ekstrak teh putih dibuat dengan cara sebagai berikut ditimbang sebanyak 2 gram teh putih, lalu diseduh dengan air suhu awal sesuai perlakuan yaitu $75 \pm 1^{\circ} \mathrm{C}, 85^{\circ} \mathrm{C} \pm 1^{\circ} \mathrm{C}$, dan $95^{\circ} \mathrm{C}$ 
$\pm 1^{\circ} \mathrm{C}$ sebanyak $100 \mathrm{ml}$. Penyeduhan dilakukan sesuai perlakuan yaitu 3 menit, 6 menit, dan 9 menit, diaduk menggunakan magnetik stirrer. Selanjutnya disaring dengan menggunakan kertas saring, sehingga diperoleh seduhan teh putih silver needle. Lalu disimpan selama 5 - 10 menit hingga suhu mencapai $35^{\circ} \mathrm{C}-40^{\circ} \mathrm{C}$ dan seduhan teh putih silver needle siap dianalisis.

\section{Variabel yang diamati}

Variabel yang diamati pada ekstrak teh putih silver needle adalah karakteristik organoleptik yaitu hedonik (penerimaan keseluruhan) dan skor warna, rasa, dan aroma (Soekarto, 1985) dan intensitas warna sistem kecerahan ( $\left.\mathrm{L}^{*}\right)$, kemerahan ( $\left.\mathrm{a}^{*}\right)$, dan kekuningan $\left(\mathrm{b}^{*}\right)$ (Weaver,1996).

\section{Karakteristik Organoleptik (Soekarto, 1985)}

Uji organoleptik teh putih silver needle dilakukan yaitu uji skoring terhadap warna, rasa, dan aroma, serta uji hedonik untuk mengetahui tingkat kesukaan panelis secara keseluruhan. Sampel seduhan teh putih silver needle dibuat dengan cara menyiapkan 2 gram teh putih silver needle dimasukkan ke dalam gelas, kemudian dimasukkan air panas suhu awal $75^{\circ} \mathrm{C}-95^{\circ} \mathrm{C}$ sebanyak $100 \mathrm{~mL}$ dan diseduh selama 3-9 menit. Ampas teh putih silver needle kemudian dikeluarkan dan didapatkan seduhan teh putih silver needle (Horzic et al, 2009). Sampel seduhan teh dihadapkan kepada panelis untuk dilakukan uji organoleptik. Uji skoring menggunakan panelis semi terlatih sebanyak 25 orang. Pada uji skoring dilakukan tahap seleksi pendahuluan berupa Uji Duo-Trio untuk mengukur kemampuan panelis dalam mendeteksi suatu sifat sensori, dimana para panelis diminta untuk menyatakan perbedaan antara tiga contoh (dua sama, satu berbeda) yang disajikan. Panelis yang lulus uji DuoTrio dapat melanjutkan tahap selanjutnya yaitu sebagai panelis uji skoring.

\section{Intensitas Warna (Weaver, 1996)}

Analisis warna dilakukan dengan colorimeter. Sampel ditempatkan dalam botol kaca bening kemudian colorimeter dihidupkan dan tombol pembacaan diatur pada $\mathrm{L}^{*}, \mathrm{a}^{*}, \mathrm{~b}^{*}$. $\mathrm{L}^{*}$ untuk parameter kecerahan (lightness), $\mathrm{a}^{*}$ dan $\mathrm{b}^{*}$ untuk koordinat kromatisitas. Notasi $\mathrm{L}^{*}$ memiliki nilai 0 (hitam) sampai dengan 100 (putih) yang menyatakan bahwa cahaya pantul menghasilkan warna akromatik putih, abuabu dan hitam. Nilai a* yang positif (0 sampai 100) menunjukkan warna merah. Sedangkan nilai negatif dari $a^{*}$ (0 sampai -100) menunjukkan warna hijau. Untuk notasi $b^{*}$ merupakan notasi dari warna kromatik campuran dari warna biru hingga kuning. Diagram akan menyatakan warna kuning apabila nilai dari $\mathrm{b}^{*}$ adalah positif (0 sampai 100) sedangkan diagram akan menunjukkan warna biru apabila nilai dari $b^{*}$ adalah negatif (0 sampai -100). Intensitas warna ( $\left.\mathrm{L}^{*}, \mathrm{a}^{*}, \mathrm{~b}^{*}\right)$ diukur dengan menempelkan ujung reseptor pada botol kaca yang berisi sampel kemudian tekan tombol target.

\section{HASIL DAN PEMBAHASAN}

\section{Karakteristik Organoleptik}

Hasil analisis keragaman menunjukkan bahwa perlakuan suhu awal dan lama penyeduhan berpengaruh sangat nyata $(\mathrm{P} \leq 0,01)$ terhadap warna, rasa, aroma dan penerimaan keseluruhan seduhan teh putih silver needle. Nilai rata-rata skoring panelis terhadap karakteristik organoleptik yaitu skor warna, rasa, aroma dan hedonik (penerimaan keseluruhan) air seduhan teh putih silver needle dapat dilihat pada Tabel 1 .

\section{Warna}

Tabel 1 menunjukkan bahwa nilai ratarata terendah dari tingkat warna teh putih silver needle pada perlakuan suhu awal $75^{\circ} \mathrm{C}$ dan lama penyeduhan 3 menit (S1W1) yaitu $1,20 \pm 0,40$ (bening sampai bening kekuningan) dan tidak berbeda dengan 
perlakuan S1W2, S2W1, dan S3W1. Nilai rata-rata tertinggi dari tingkat warna teh putih silver needle perlakuan suhu awal $85^{\circ} \mathrm{C}$ dan lama penyeduhan 9 menit (S2W3) yaitu 2,80 $\pm 0,57$ (bening kekuningan sampai kuning) tidak berbeda dengan perlakuan S2W2 dan S3W3. Hal ini menunjukkan semakin tinggi perlakuan suhu awal dan lama penyeduhan menyebabkan senyawa yang terkandung dalam teh terekstrak banyak, hal ini disebabkan oleh kesempatan kontak antara air penyeduh dengan teh semakin lama sehingga proses ekstraksi menjadi lebih sempurna dan kandungan polifenol total semakin meningkat (Rohdiana, 2008). Semakin tinggi suhu air yang digunakan pada proses penyeduhan maka, kemampuan air dalam mengekstrak kandungan kimia yang terdapat dalam teh akan semakin tinggi menyebabkan teroksidasi senyawa tannin yang berubah menjadi teaflavin dan tearubigin mengakibatkan warna seduhan teh putih silver needle meningkat.

Tabel 1. Nilai rata-rata skoring warna, rasa, aroma dan hedonik (penerimaan keseluruhan) seduhan teh putih silver needle pada perlakuan suhu awal dan lama penyeduhan.

\begin{tabular}{ccccc}
\hline \multirow{2}{*}{ Perlakuan } & \multicolumn{4}{c}{ karakteristik organoleptik } \\
\cline { 2 - 5 } & Warna & Rasa & Aroma & $\begin{array}{c}\text { Penerimaan } \\
\text { keseluruhan }\end{array}$ \\
\hline S1W1 (75 $\mathrm{C}, 3$ menit) & $1,20 \pm 0,40^{\mathrm{c}}$ & $1,68 \pm 0,47^{\mathrm{e}}$ & $2,68 \pm 0,47^{\mathrm{e}}$ & $5,16 \pm 0,47^{\mathrm{c}}$ \\
S1W2 (75 $\mathrm{C}, 6$ menit) & $1,48 \pm 0,53^{\mathrm{c}}$ & $2,48 \pm 0,51^{\mathrm{cd}}$ & $3,20 \pm 0,64^{\mathrm{bcd}}$ & $5,48 \pm 0,45^{\mathrm{bc}}$ \\
S1W3 (75 ${ }^{\circ} \mathrm{C}, 9$ menit) & $1,96 \pm 0,61^{\mathrm{b}}$ & $3,24 \pm 0,59^{\mathrm{b}}$ & $3,56 \pm 0,50^{\mathrm{b}}$ & $6,16 \pm 0,58^{\mathrm{b}}$ \\
S2W1 (85 ${ }^{\circ} \mathrm{C}, 3$ menit) & $1,36 \pm 0,48^{\mathrm{c}}$ & $1,88 \pm 0,52^{\mathrm{e}}$ & $2,84 \pm 0,47^{\mathrm{de}}$ & $5,32 \pm 0,52^{\mathrm{c}}$ \\
S2W2 (85 ${ }^{\circ} \mathrm{C}, 6$ menit) & $2,36 \pm 0,47^{\mathrm{ab}}$ & $2,64 \pm 0,48^{\mathrm{c}}$ & $3,36 \pm 0,48^{\mathrm{bc}}$ & $5,56 \pm 0,48^{\mathrm{bc}}$ \\
S2W3 (85 ${ }^{\circ} \mathrm{C}, 9$ menit) & $2,80 \pm 0,57^{\mathrm{a}}$ & $3,52 \pm 0,58^{\mathrm{b}}$ & $3,48 \pm 0,58^{\mathrm{b}}$ & $5,88 \pm 0,59^{\mathrm{ab}}$ \\
S3W1 (95 ${ }^{\circ} \mathrm{C}, 3$ menit) & $1,32 \pm 0,48^{\mathrm{c}}$ & $2,04 \pm 0,45^{\mathrm{de}}$ & $3,00 \pm 0,28^{\mathrm{cde}}$ & $5,56 \pm 0,48^{\mathrm{bc}}$ \\
S3W2 (95 ${ }^{\circ} \mathrm{C}, 6$ menit) & $2,04 \pm 0,61^{\mathrm{b}}$ & $3,28 \pm 0,45^{\mathrm{b}}$ & $4,40 \pm 0,50^{\mathrm{a}}$ & $5,88 \pm 0,59^{\mathrm{b}}$ \\
S3W3 (95 ${ }^{\circ} \mathrm{C}, 9$ menit) & $2,40 \pm 0,64^{\mathrm{a}}$ & $4,24 \pm 0,43^{\mathrm{a}}$ & $4,48 \pm 0,51^{\mathrm{a}}$ & $6,20 \pm 0,43^{\mathrm{a}}$
\end{tabular}

Keterangan: huruf yang berbeda di belakang nilai rata-rata pada kolom yang sama menunjukkan perbedaan yang nyata pada taraf kesalahan $5 \%(\mathrm{P} \leq 0,05)$.

\section{Rasa}

Tabel 1 menunjukkan nilai rata-rata terendah di peroleh dari perlakuan suhu awal $75^{\circ} \mathrm{C}$ dan lama penyeduhan 3 menit (S1W1) yaitu $1,68 \pm 0,47$ (sepat sampai agak sepat) tidak berbeda dengan perlakuan S2W1. Nilai rata-rata tertinggi diperoleh dari perlakuan suhu awal $95^{\circ} \mathrm{C}$ dan lama penyeduhan 9 menit (S3W3) yaitu 4,24 $\pm 0,43$ (agak manis sampai manis). Semakin tinggi suhu dan lama penyeduhan kemampuan air dalam mengektraksi senyawa yang terkandung dalam teh semakin sempurna sehingga memunculkan rasa yang manis dan lembut.

Rasa manis dikarenakan pada pucuk peko teh putih silver needle masih terdapat kandungan senyawa glukosa yang menyebabkan rasa manis pada seduhan teh putih silver needle. Menurut Winarno (2002) rasa dipengaruhi beberapa faktor, yaitu senyawa kimia, suhu, konsentrasi dan waktu. Rasa yang terdapat dalam minuman teh merupakan kombinasi dari perlakuan suhu dan waktu penyeduhan. Karakteristik teh pada umumnya adalah rasa astrigency atau sepet, pada teh putih menghasilkan rasa umami, grassy, dan sweet. Perlakuan suhu awal $95^{\circ} \mathrm{C}$ dan lama penyeduhan 9 menit merupakan produk terbaik dengan skoring rasa yaitu $4,24 \pm 0,43$ agak manis sampai manis.

\section{Aroma}

Tabel 1 menunjukkan bahwa nilai ratarata terendah diperoleh dari perlakuan suhu 
awal $75^{\circ} \mathrm{C}$ dan lama penyeduhan 3 menit (S1W1) yaitu 2,68 $\pm 0,47$ (tidak beraroma teh sampai agak beraroma teh). Nilai rata-rata tertinggi diperoleh dari perlakuan suhu awal $95^{\circ} \mathrm{C}$ dan lama penyeduhan 9 menit (S3W3) yaitu 4,48 $\pm 0,51$ (beraroma teh sampai sangat beraroma teh) tidak berbeda dengan perlakuan S3W2. Hal ini disebabkan karena setiap perlakuan suhu awal dan lama penyeduhan yang lebih tinggi menyebabkan terekstraksinya senyawa linalool dan B-lonon menghasilkan aroma teh putih menjadi sangat khas. Menurut Ciptadi dan Nasution (1979) senyawa pembentuk aroma teh terutama terdiri dari minyak atsiri yang terkandung pada teh hitam yang bersifat mudah menguap dan bersifat mudah direduksi, sehingga dapat menghasilkan aroma harum pada teh

\section{Penerimaan keseluruhan}

Tabel 1 menunjukkan nilai rata-rata tertinggi diperoleh dari perlakuan suhu awal $95^{\circ} \mathrm{C}$ dan lama penyeduhan 9 menit (S3W3)

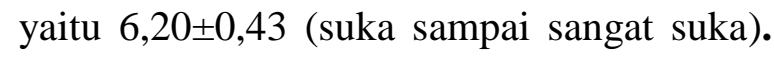
Nilai rata-rata terendah diperoleh dari perlakuan suhu awal $75^{\circ} \mathrm{C}$ dan lama penyeduhan 3 menit (S1W1) yaitu 5,16 $\pm 0,47$ (agak suka sampai suka) tidak berbeda dengan perlakuan S2W1. Nilai rata-rata uji penerimaan keseluruhan terhadap seduhan teh putih silver needle yaitu antara 5,16 $\pm 0,47$

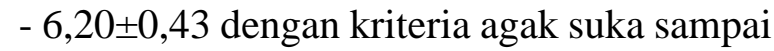
sangat suka. Perlakuan suhu awal $95^{\circ} \mathrm{C}$ dan lama penyeduhan 9 menit merupakan produk yang paling disukai oleh panelis berdasarkan dari segi warna, rasa dan aroma.

\section{Intensitas Warna}

Hasil analisis keragaman menunjukkan bahwa perlakuan suhu awal dan lama penyeduhan berpengaruh sangat nyata $(\mathrm{P}<0,01)$ dan interaksi kedua perlakuan berpengaruh nyata $(\mathrm{P}<0,05)$ terhadap tingkat kecerahan $\left(\mathrm{L}^{*}\right)$, kemerahan $\left(\mathrm{a}^{*}\right)$ dan kekuningan $\left(\mathrm{b}^{*}\right)$ seduhan teh putih silver needle dapat dilihat pada Tabel 2 .

Tabel 2. Nilai rata-rata tingkat kecerahan $\left(\mathrm{L}^{*}\right)$, kemerahan $\left(\mathrm{a}^{*}\right)$ dan kekuningan $\left(\mathrm{b}^{*}\right)$ seduhan teh putih silver needle pada perlakuan suhu awal dan lama penyeduhan.

\begin{tabular}{cccc}
\hline \multirow{2}{*}{ Perlakuan } & \multicolumn{3}{c}{ Intesitas Warna $\left(\mathrm{L}^{*}, \mathrm{a}^{*}, \mathrm{~b}^{*}\right)$} \\
\cline { 2 - 4 } & Kecerahan & Kemerahan & Kekuningan \\
\hline S1W1 $\left(75^{\circ} \mathrm{C}, 3\right.$ menit $)$ & $59,37 \pm 0,30^{\mathrm{a}}$ & $12,40 \pm 0,07^{\mathrm{e}}$ & $40,40 \pm 0,07^{\mathrm{a}}$ \\
S1W2 $\left(75^{\circ} \mathrm{C}, 6\right.$ menit $)$ & $58,42 \pm 0,30^{\mathrm{b}}$ & $13,37 \pm 0,03^{\mathrm{d}}$ & $39,37 \pm 0,30^{\mathrm{b}}$ \\
S1W3 $\left(75^{\circ} \mathrm{C}, 9\right.$ menit) & $57,32 \pm 0,30^{\mathrm{c}}$ & $14,32 \pm 0,30^{\mathrm{c}}$ & $38,32 \pm 0,03^{\mathrm{c}}$ \\
S2W1 $\left(85^{\circ} \mathrm{C}, 3\right.$ menit $)$ & $58,25 \pm 0,07^{\mathrm{b}}$ & $13,25 \pm 0,07^{\mathrm{d}}$ & $39,25 \pm 0,07^{\mathrm{b}}$ \\
S2W2 $\left(85^{\circ} \mathrm{C}, 6\right.$ menit) & $57,25 \pm 0,07^{\mathrm{c}}$ & $14,27 \pm 0,03^{\mathrm{c}}$ & $38,22 \pm 0,03^{\mathrm{d}}$ \\
S2W3 $\left(85^{\circ} \mathrm{C}, 9\right.$ menit $)$ & $56,45 \pm 0,21^{\mathrm{d}}$ & $15,45 \pm 0,21^{\mathrm{b}}$ & $37,45 \pm 0,21^{\mathrm{e}}$ \\
S3W1 $\left(95^{\circ} \mathrm{C}, 3\right.$ menit $)$ & $57,62 \pm 0,03^{\mathrm{c}}$ & $14,55 \pm 0,07^{\mathrm{c}}$ & $38,62 \pm 0,03^{\mathrm{c}}$ \\
S3W2 $\left(95^{\circ} \mathrm{C}, 6\right.$ menit) & $56,72 \pm 0,10^{\mathrm{d}}$ & $15,72 \pm 0,10^{\mathrm{b}}$ & $37,72 \pm 0,10^{\mathrm{e}}$ \\
S3W3 $\left(95^{\circ} \mathrm{C}, 9\right.$ menit $)$ & $55,32 \pm 0,17^{\mathrm{e}}$ & $16,32 \pm 0,17^{\mathrm{a}}$ & $36,37 \pm 0,10^{\mathrm{e}}$ \\
\hline
\end{tabular}

Keterangan: huruf yang berbeda di belakang nilai rata-rata pada kolom yang sama menunjukkan perbedaan yang nyata pada taraf kesalahan $5 \%(\mathrm{P} \leq 0,05)$.

\section{Tingkat Kecerahan (L*)}

Nilai tingkat kecerahan $\left(\mathrm{L}^{*}\right)$ menyatakan tingkat gelap sampai terang dengan kisaran 0-100. Semakin besar nilai L* menunjukkan kecenderungan warna yang semakin terang.

Tabel 2 menunjukkan bahwa nilai ratarata tingkat kecerahan tertinggi diperoleh dari perlakuan suhu awal $75^{\circ} \mathrm{C}$ dan lama penyeduhan 3 menit (S1W1) dengan nilai rata-rata 59,37 $\pm 0,3$. Sedangkan nilai rata-rata tingkat kecerahan terendah diperoleh dari perlakuan suhu awal $95^{\circ} \mathrm{C}$ dan lama penyeduhan 9 menit (S3W3) dengan nilai rata-rata $55,32 \pm 0,17$. Tingkat kecerahan yang dihasilkan pada suhu awal dan lama 
penyeduhan menunjukkan bahwa terjadi penurunan tingkat kecerahan seduhan teh putih silver needle dengan semakin meningkatnya suhu dan lama penyeduhan. Hal ini disebabkan oleh senyawa bioaktif yang terkandung pada seduhan teh putih silver needle dengan perlakuan S3W3 terekstrak lebih banyak sehingga tingkat kecerahan yang dihasilkan semakin rendah (gelap). Penelitian Rohdiana et al. (2008) menunjukkan bahwa semakin tinggi suhu air dan lama penyeduhan akan mempengaruhi intensitas warna. Kemampuan air dalam mengekstrak kandungan kimia yang terdapat dalam teh akan semakin tinggi dan kesempatan kontak antara air penyeduh dengan teh semakin lama sehingga proses ekstraksi menjadi lebih sempurn. Perlakuan tingkat kecerahan terendah yaitu S3W3 memiliki nilai sensoris warna bening kekuningan sampai kuning

\section{Tingkat kemerahan $\left(a^{*}\right)$}

Nilai $a^{*}$ menunjukkan kecenderungan warna dari hijau sampai merah dengan kisaran nilai - 100 sampai +100 . Semakin besar nilai a* menunjukkan kecenderungan warna yang semakin merah.

Tabel 2 menunjukkan bahwa nilai ratarata tingkat kemerahan tertinggi diperoleh dari perlakuan suhu awal $95^{\circ} \mathrm{C}$ dan lama penyeduhan 9 menit (S3W3) dengan nilai rata-rata $16,32 \pm 0,17$. Sedangkan nilai ratarata tingkat kemerahan terendah diperoleh dari perlakuan suhu awal $75^{\circ} \mathrm{C}$ dan lama penyeduhan 3 menit (S1W1) dengan nilai rata-rata $12,40 \pm 0,07$. Tingkat kemerahan yang dihasilkan pada suhu awal dan lama penyeduhan menunjukkan peningkatan warna kemerahan seduhan teh putih silver needle, dikarenakan proses penyeduhan akan menyebabkan teh teroksidasi, karena oksidasi ini berperan dalam merubah tannin menjadi teaflavin dan tearubigin. Teaflavin berperan dalam penentuan kecerahan warna seduhan teh (kuning kemerahan) dan Tearubigin merupakan senyawa yang sulit larut dalam air dan berperan dalam menentukan warna seduhan teh (merah kecoklatan agak gelap) (Rohdiana, 2004). Hasil ini berhubungan dengan sensoris warna yang dihasilkan dalam penilaiain skoring, semakin tinggi suhu awal dan lama penyeduhan maka tingkat kemerahan akan semakin meningkat.

\section{Tingkat kekuningan (b*)}

Nilai tingkat kekuningan $\left(b^{*}\right)$ menyatakan tingkat warrna biru sampai kuning dengan kisaran -100 sampai +100 . Semakin besar nilai $b^{*}$ menunjukkan kecenderungan warna yang semakin kuning.

Tabel 2 menunjukkan bahwa nilai ratarata tingkat kekuningan tertinggi diperoleh dari perlakuan suhu awal $75^{\circ} \mathrm{C}$ dan lama penyeduhan 3 menit (S1W1) dengan nilai rata-rata $40,40 \pm 0,07$. Sedangkan nilai ratarata tingkat kekuningan terendah diperoleh dari perlakuan suhu awal $95^{\circ} \mathrm{C}$ dan lama penyeduhan 9 menit (S3W3) dengan nilai rata-rata $36,37 \pm 0,10$ dan tidak berbeda dengan perbandingan S3W2 dan S2W3. Tingkat kekuningan yang dihasilkan pada suhu awal dan lama penyeduhan menunjukkan bahwa penurunan tingkat kekuningan seduhan teh putih silver needle dengan semakin meningkatnya suhu dan lama penyeduhan. Penurunan tingakat kekuningan terjadi karena teh teroksidasi menyebabkan kandungan senyawa kimia meningkat yang mengakibatkan perubahan warna seduhan teh. Penelitian Pitojo dan Zumiati (2009) menyatakan bahwa tannin terurai dalam air panas atau air dingin dan membentuk system koloidal, sebagai akibat dari pemanasan dengan konsentrasi tinggi, menimbulkan warna coklat atau merah coklat. Dengan nilai rata-rata tingkat kekuningan tertinggi 40,40 $\pm 0,07$ mengahsilkan kisaran warna bening kekuningan samapi kunin kemerahan.

\section{Hasil Uji Indeks Efektivitas Produk Seduhan Teh Putih Silver Need}

Uji indeks efektivitas dilakukan untuk 
menentukan perlakuan terbaik dalam menghasilkan produk seduhan teh putih silver needle. Variabel yang diamati dalam uji indeks efektivitas ini yaitu, warna, rasa, aroma, hedonik, tingkat kecerahan ( $\left.\mathrm{L}^{*}\right)$, tingkat kemerahan $\left(\mathrm{a}^{*}\right)$, dan tingkat kekuningan $\left(b^{*}\right)$. Hasil uji indeks efektivitas dapat dilihat pada Tabel 3 .

Tabel 3. Hasil uji indeks efektivitas untuk menentukan perlakuan terbaik produk seduhan teh putih

\begin{tabular}{lllllllllr}
\hline Variabel & & Warna & Rasa & Aroma & Hedonik & $\begin{array}{l}\text { Kecerahan } \\
\left(\mathrm{L}^{*}\right)\end{array}$ & $\begin{array}{l}\text { Kemerahan } \\
\left(\mathrm{a}^{*}\right)\end{array}$ & $\begin{array}{l}\text { Kekuningan } \\
(\mathrm{b})\end{array}$ & Jumlah \\
\hline \multirow{5}{*}{ S1W1 } & $\mathrm{BV}$ & 5,2 & 6,0 & 6,0 & 6,6 & 4,6 & 4,8 & 3,8 & 37,00 \\
& $\mathrm{Ne}$ & 0,14 & 0,16 & 0,16 & 0,18 & 0,12 & 0,13 & 0,10 & 1,00 \\
S1W2 & $\mathrm{Nh}$ & 0,00 & 0,00 & 0,00 & 0,00 & 0,00 & 0,00 & 1,00 & \\
& $\mathrm{Ne}$ & 0,18 & 0,00 & 0,00 & 0,00 & 0,00 & 0,00 & 0,10 & 0,10 \\
S1W3 & $\mathrm{Ne}$ & 0,02 & 0,05 & 0,05 & 0,06 & 0,03 & 0,03 & 0,07 & 0,31 \\
& $\mathrm{Nh}$ & 0,48 & 0,49 & 0,61 & 0,96 & 0,51 & 0,49 & 0,48 & \\
S2W1 & $\mathrm{Ne}$ & 0,10 & 0,09 & 0,10 & 0,17 & 0,06 & 0,06 & 0,05 & 0,59 \\
& $\mathrm{Nh}$ & 0,01 & 0,00 & 0,01 & 0,03 & 0,03 & 0,03 & 0,71 & \\
S2W2 & $\mathrm{Ne}$ & 0,70 & 0,38 & 0,38 & 0,38 & 0,52 & 0,48 & 0,46 & 0,20 \\
& $\mathrm{Nh}$ & 0,10 & 0,06 & 0,06 & 0,07 & 0,06 & 0,06 & 0,05 & 0,46 \\
S2W3 & $\mathrm{Ne}$ & 1,00 & 0,44 & 0,72 & 0,69 & 0,72 & 0,78 & 0,27 & \\
& $\mathrm{Nh}$ & 0,14 & 0,07 & 0,12 & 0,12 & 0,09 & 0,10 & 0,03 & 0,67 \\
S3W1 & $\mathrm{Ne}$ & 0,08 & 0,18 & 0,14 & 0,38 & 0,43 & 0,55 & 0,56 & \\
& $\mathrm{Nh}$ & 0,01 & 0,03 & 0,02 & 0,07 & 0,05 & 0,07 & 0,06 & 0,31 \\
S3W2 & $\mathrm{Ne}$ & 0,53 & 0,96 & 0,63 & 0,69 & 0,65 & 0,85 & 0,33 & \\
& $\mathrm{Nh}$ & 0,07 & 0,15 & 0,10 & 0,12 & 0,08 & 0,11 & 0,03 & 0,67 \\
S3W3 & $\mathrm{Ne}$ & 0,75 & 1,00 & 1,00 & 1,00 & 1,00 & 1,00 & 0,00 & \\
& $\mathrm{Nh}$ & 0,11 & 0,16 & 0,16 & 0,18 & 0,12 & 0,13 & 0,00 & $\mathbf{0 , 8 6}$ \\
\hline
\end{tabular}

Perlakuan terbaik ditunjukkan dengan jumlah nilai hasil tertinggi. Perlakuan suhu awal $95^{\circ} \mathrm{C}$ dan lama penyeduhan 9 menit mempunyai nilai hasil tertinggi yaitu 0,86 sehingga merupakan perlakuan terbaik untuk menghasilkan seduhan teh putih silver needle.

\section{KESIMPULAN}

\section{Kesimpulan}

Berdasarkan penelitian yang telah dilakukan maka dapat disimpulkan beberapa hal sebagai berikut:

1. Interaksi antara perlakuan suhu awal dan lama penyeduhan sangat berpengaruh terhadap uji karakteristik organoleptik (skoring warna, rasa, aroma dan penerimaan keseluruhan) dan berpengaruh terhadap tingkat kecerahan $\left(\mathrm{L}^{*}\right)$, tingkat kemerahan $\left(\mathrm{a}^{*}\right)$, dan tingkat kekuningan $\left(b^{*}\right)$.

2. Perlakuan suhu awal $95^{\circ} \mathrm{C}$ dan lama penyeduhan 9 menit merupakan perlakuan terbaik untuk menghasilkan seduhan teh putih silver needle dengan karakteristik

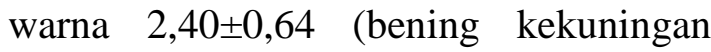
sampai kekuningan), rasa 4,24 $\pm 0,43$ (agak manis sampai manis), aroma $4,48 \pm 0,51$ (beraroma teh sampai sangat beraroma teh), penerimaan keseluruhan6,20 $\pm 0,43$ (suka sampai sangat suka), tingkat kecerahan ( $\left.\mathrm{L}^{*}\right) \quad 55,32 \pm 0,17$, tingkat 
kemerahan (a*) 16,32 $\pm 0,17$, tingkat

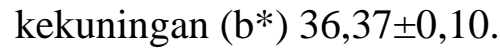

\section{Saran}

Berdasarkan hasil penelitian, untuk menghasilkan produk teh putih terbaik disarankan menggunakan suhu awal penyeduhan $95^{\circ} \mathrm{C}$ dengan lama penyeduhan 9 menit. Perlu dilakukan penelitian lebih lanjut mengenai hubungan antara karakteristik sensoris dengan komposisi kimia teh.

\section{DAFTAR PUSTAKA}

Antara, N.S., and M. Wartini, 2014. Aroma and Flavor Compounds. Tropical Plant Curriculum Project Udayana University - Texas A\&M University.

Ciptadi, W. dan M.Z. Nasution. 1979. Mempelajari Cara Pemanfaatan Teh Hitam Mutu Rendah untuk Pembuatan Teh Dadak. IPB, Bogor.

De Garmo, E. P., W. G. Sullivan, and C. R. Canada. 1984. Engineering Economy. Macmilan Publisher, New York.

Dewata, I.P., P. A. S. Wipradnyadewi, dan I.W. R. Widarta. 2017. Pengaruh suhu dan lama penyeduhan terhadap aktivitas antioksidan dan sifat sensoris teh herbal daun alpukat (Persea americana Mill.). Jurnal ITEPA. 6 (2): 30-39.

Dias, T.R., G. Tomás, N.F. Teixeira, M.G. Alves, P.F. Oliveira, and B.M. Silva. 2013. White tea (Camellia sinensis) antioxidant properties and beneficial health effects. International Journal of Food Science. Nutrition and Dietetics (IJFS). 2(2): 101-106.

Gramza, A.M. 2008. Antioxidant potential and radical scavenging activityof different fermentation degree tea leaves extracts. ACTA Scientiarum Polonorum. Technologia Alimentaria.
7(4): 15-28.

Haras, M.S., J. R. Assa, dan T. Langi. 2017. Tingkat penerimaan konsumen terhadap teh daun binahong (Anredera cordifolia (Ten.) Steenis) pada variasi suhu dan waktu penyeduhan. Jurnal Teknologi Pertanian. 1(6): 30-37.

Hayati, R, Marliah, A, dan Rosita, F. 2012. Sifat kimia dan evaluasi sensori bubuk kopi arabika. Jurnal Florstek. 1(7): 6675.

Horzic, D., D. Komes, A. Belscak., K.K. Ganic., D. Ivekovic and D. Karlovic. 2009. The compositions of polyphenols and methylxantine in teas and herbal infusions. Food Chem. 115(2):441-448.

Pitojo, S. dan Zumiati. 2009. Pewarna Nabati Makanan. Kanisius, Yogyakarta.

Prabawati, I.R. 2015. Karakterisasi Teh Berbahan Dasar Teh Hijau, Kulit Lidah Buaya dan Jahe dengan Variasi Komposisi dan Suhu Penyeduhan. Skripsi. Tidak dipublikasikan. Jurusan Teknologi Hasil Pertanian, Fakultas Teknologi Pertanian, Universitas Jember, Jember.

Ramlah. 2017. Penentuan Suhu dan Waktu Optimum Penyeduhan Daun Teh Hijau (Camellia sintesis L.) $\mathrm{P}+2$ terhadap Kandungan Antioksidan Kafein, Tanin dan Katekin. Skripsi. Tidak dipublikasikan. Fakultas Sains dan Teknologi, UIN Alauddin, Makassar.

Rohdiana, D. dan W. Tanta. 2004. Aktifitas Antioksidan Beberapa Klon Teh Unggulan, Prosiding Seminar Nasional dan Kongres Perhimpunan Ahli Teknologi Pangan Indonesia (PATPI). Jakarta.

Rohdiana, D., W. Cahyadi, dan T. Risnawati. 2008. Aktivitas penangkapan radikal bebas DPPH (1,1-Diphenyl-2Picrylhidrazyl) beberapa jenis 
minuman. Jurnal Teknologi Pertanian. 3(2):79-81.

Soekarto, T.S. 1985. Penilaian Organoleptik untuk Industri Pangan dan Hasil Pertanian. Bharata Karya Aksara, Jakarta.

Somantri, M. 2012. Analisis Polifenol Total dan Aktivitas Penangkapan Radikal Bebas Dpph (1,1-Diphnyl, 2Picrylhidrazl) Teh Putih (Camellia sinensis L.O. Kuntze) Berdasarkan Suhu dan Lama Penyeduhannya. Skripsi. Tidak dipublikasikan. Jurusan Teknologi Pangan, Fakultas Teknik, Universitas Pasundan, Bandung.

Weaver, C. 1996. The Food Chemistry Laboratory. CRC Press, Boca Raton, New York, London, Tokyo.

Winarno FG. 2002. Kimia Pangan dan Gizi. PT. Gramedia, Jakarta. 